\title{
Combination and superimposition of source kitchens and their effects on hydrocarbon accumulation in the hinterland of the Junggar Basin, west China
}

\author{
Zhang Zhihuan ${ }^{1 *}$, Qin Liming ${ }^{1}$, Qiu Nansheng ${ }^{1}$, Zhong Ningning ${ }^{1}$, \\ Zhang Zhenying ${ }^{2}$ and Li Wei ${ }^{1,3}$ \\ ${ }^{1}$ State Key Laboratory of Petroleum Resources and Prospecting, China University of Petroleum, Beijing 102249, China \\ ${ }^{2}$ Beijing Institute of Economic Management, Hebei 102602, China \\ ${ }^{3}$ SINOPEC International Petroleum Exploration and Production Corporation, Beijing 100083, China
}

(C) China University of Petroleum (Beijing) and Springer-Verlag Berlin Heidelberg 2010

\begin{abstract}
In the hinterland of the Junggar Basin, there are multiple depressions with multiple sets of source rocks. Therefore, the conditions of hydrocarbon sources are complex, and the geochemical characteristics and sources of hydrocarbon vary in different structural belts. The evolution of the CheMo palaeohigh affected the formation of hydrocarbon source kitchens and hydrocarbon migration. We studied the combination and superimposition of hydrocarbon source kitchens, using as an example the hinterland of the Junggar Basin (including the Yongjin, Zhengshacun, Moxizhuang and Luliang uplift areas). The study was based on geochemical analyses of crude oil and fluid inclusions, and the histories of tectonic evolution and hydrocarbon generation. The results indicated that before the Paleogene there were two hydrocarbon-generating depressions: the Western Well Pen 1 depression and the Changji depression on the south and north sides of the Che-Mo palaeohigh, respectively. The Permian source kitchen had been generating hydrocarbon continuously since Triassic and reached high maturity stage in the Cretaceous period. After Paleogene, the adjustment of the Che-Mo palaeohigh led to the subsidence of the Changji depression and the Jurassic source rocks reached mature stage and became the main source kitchens. However, the Jurassic source rocks in the Western Well Pen1 depression were still in a low maturity stage and did not generate oil because of the adjustment of tectonic movements. As a result, in the central and southern parts of the Junggar Basin, Jurassic source rocks generated oil, but in the Luliang uplift, the crude oil was from the Permian source rocks in the Western Well Pen1 depression and the Jurassic source rocks did not contribute. The crude oil in the central Zhengshacun-Moxizhuang belt was from the Permian source rocks in two depressions, and partially from the Jurassic source rocks. The crude oil in the Luliang uplift was from the source rocks of the lower Permian Fengcheng Formation and middle Permian Wuerhe Formation, which is characterized by superimposition of two sets of source kitchens and three accumulation stages. The crude oil in the Yongjin tectonic belt was from the lower Permian, middle Permian and Jurassic source rocks, which is characterized by superimposition of three sets of source kitchens and two accumulation stages. The crude oil in the Zhengshacun tectonic belt was from a combination of source kitchens of lower Permian and middle Permian in the Western Well Pen1 depression in the early stage and from the superimposition of Jurassic source rocks in the Changji depression in the late stage.
\end{abstract}

Key words: Hinterland of the Junggar Basin, hydrocarbon source kitchen, oil source, combination and superimposition, accumulation stage

\section{Introduction}

Oilfields are widely distributed in the northwestern margin, hinterland, eastern part and southern margin of the Junggar Basin, west China. In the hinterland, many uplifts

*Corresponding author. email: zhangzh3996@vip.163.com Received September 4, 2009 have developed including the Luliang, Maqiao, Mobei and Dabasong uplifts and the Che-Mo paleo-uplift. Currently, commercial oil has been discovered in the Madong, Xiayan, Shinan, Shixi, Lunan oilfields and Maqiao uplift. Some oil layers have also been discovered in the Jurassic Badaowan and Sangonghe formations in the Moxizhuang, Shawodi and Zhengshacun areas of the hinterland, and in the Jurassic Xishanyao, Sangonghe, Badaowan formations and Cretaceous 
Tugulu Group in the Yongjin area.

In the hinterland of the Junggar Basin, there were many depressions and multiple sets of source rocks were developed. The crude oil mainly derives from the lower Permian Fengcheng Formation, middle Permian Wuerhe Formation and Jurassic source rocks in the Western Well Penl depression, and the middle Permian Lucaogou and Hongyanchi formations and Jurassic source rocks in the Changii depression. The oil sources are complex and are different in different tectonic belts. For example, the oilfields in the Mabei, Xiayan and Madong areas are distributed around the Mahu depression and the oil in these areas derives from the lower Permian Fengcheng Formation. The high content of tricyclic terpanes of the crude oil in the Mabei, Xiayan and Madong areas shows long-distance migration. The crude oil in the Shinan oilfield derives from the Permian Wuerhe Formation in the Western Well Pen1 depression. The geochemical characteristics of the crude oil in the Shixi oilfield are complex, which may be related to the long-distance migration of hydrocarbon, and the oil also originates from the Wuerhe Formation in the Western Well Penl depression. In the east of the Lunan uplift, the crude oil in the Mobei, Maqiao and Well Lunanl areas derives mainly from the Permian source rocks and partially from the Jurassic source rocks (Zhang et al, 2000). Source rocks in the Western Well Pen1, Changii and northern Dongdaohaizi depressions all contribute to the oil in the Mosuowan-Mobei area and the Western Well Penl depression is the main hydrocarbon source area (Gao et al, 2007).

Oil accumulation in the hinterland of the Junggar Basin is controlled by the source rock horizon, source kitchen location and its evolution, tectonic evolution and regional migration conditions. Using the southern Yongjin area, central Zhengshacun-Moxizhuang area and northern Luliang uplift as an example, we studied the combination and superimposition of hydrocarbon source kitchens. The study was based on the geochemical characteristics of the crude oil, the geochemical analysis of fluid inclusions and included data on tectonic evolution and hydrocarbon generation of source rocks. We also discussed the correlations between oil accumulation and evolution of source rocks as well as regional migration conditions, especially the influence of the evolution of the Che-Mo palaeohigh on the formation and transformation of hydrocarbon source kitchens and hydrocarbon migration and accumulation in the study area.

\section{Geological background}

In the hinterland of the Junggar Basin, there have been five uplifts: Sangequan, Shixi, Mobei, Monan and Mosuowan, and two hydrocarbon-generating depressions: Western Well Penl and Shawan (i.e. west section of the Changji depression) with Jurassic and Permian source rocks (Kuang et al, 2001). At present, many oil layers have been discovered in the Luliang uplift, Mosuowan uplift and Yongjin-Zhengshacun area (Fig. 1). The Luliang low uplift is located adjacent to

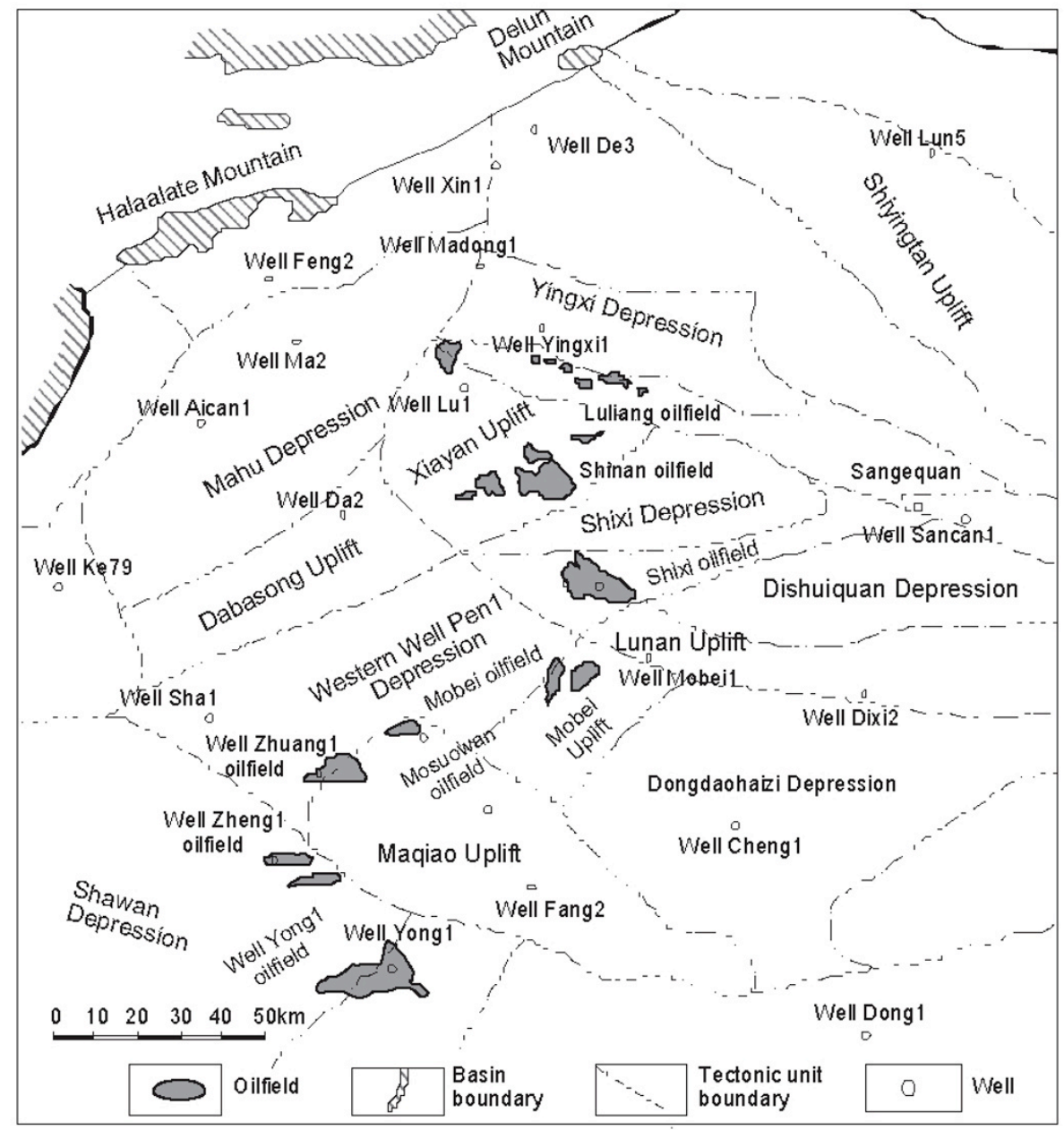

Fig. 1 Main oilfields in the hinterland of the Junggar Basin 
the Shixi and Shinan sags, and drape anticline, reverse drag anticline, fault block, fault nose and structural-lithological traps all occur. These traps are mainly controlled by the paleo-tectonic framework, and were gradually formed due to continuous development and long-term evolution of the paleo-uplifts. The Mobei uplift, adjacent to the Luliang uplift on the north, to the Maqiao uplift on the south, to the northern Dongdaohaizi depression on the east, and to the Western Well Pen 1 depression on the west, is a "nose" uplift dipping to southwest between the well Shixi-1 fracture and the Mobei No.1 fracture, and the main reservoir types are structural and lithological reservoirs. The source rocks in different depressions or in different layers of the same depression did not generate oil at the same time, which led to multi-source and multi-stage hydrocarbon supply in the study area (Qiu et al, 2001). Moreover, four movements including Hercynian, Indo-China, Yanshan and Himalayan occurred in this area, which led to multi-stage hydrocarbon accumulation (Kuang et al, 2001).

The formation and distribution of the reservoirs are significantly controlled by the evolution of the Che-Mo palaeohigh (Cai and Liu, 2005). In the late period of the middle Jurassic, there was a large low uplift across the whole hinterland of the Junggar Basin along the CheguaiMosuowan-Lunan belt. This is called the Che-Mo palaeohigh and it splits the Junggar Basin into southern and northern subsidence zones. The northern subsidence zone is in the Wulungu depression, and the southern subsidence zone is in the Changji-Wucaiwan depression. As shown in Fig. 2, the Che-Mo palaeohigh was initially formed in the early Jurassic Sangonghe Formation and the Moxizhuang-Shawodi and Yongjin structures occurred to the south and north of the CheMo palaeohigh, respectively. During the middle-late Jurassic, influenced by the Yanshan tectonic movement, the CheMo palaeohigh began to uplift intensely, and the structural high position was near the Zhengshacun area. Before the deposition of the early Cretaceous to Miocene Shawan Formation, the Che-Mo palaeohigh was buried, and still had an anticline pattern trending east-west, but the structural high position changed. In the deposition period of the Shawan Formation of Miocene, because of the rapid subsidence of the southern area, the structural high position of the palaeohigh continued migrating gradually to the north. At the end of the deposition of the Shawan Formation, it migrated to the well Zhuang1 around again and the local structural high position in the south began to disappear. During the deposition of the Miocene Taxihe Formation, the southern part subsided more intensely, but the northern part of the palaeohigh further uplifted. So, the present tectonic framework of "south dipping and north uplifting" was formed and the Che-Mo palaeohigh finally disappeared. The formation and location of the Che-Mo palaeohigh not only control the local structural characteristics in the study area, but also restrict the evolution of source rocks and the migration, accumulation and adjustment of hydrocarbon in depressions, which lead to complex oil sources and hydrocarbon distribution.

\section{Source conditions in the hinterland of the Junggar Basin}

There are two hydrocarbon-generating depressions in the hinterland of the Junggar Basin, which are Western Well Pen1 in the north and Shawan in the south with effective Jurassic and Cretaceous source rocks.

\subsection{Geochemical characteristics of source rocks in the Western Well Pen1 depression and its adjacent regions}

The Western Well Pen 1 depression contains Cretaceous, Jurassic, Triassic and Permian strata, and the basement is Carboniferous. Two sets of source rocks were developed in the Jurassic and Permian strata. The organic matter abundance of dark mudstones of the Jurassic Sangonghe Formation is medium and that of the Badaowan Formation is relatively high, both with the organic matter mainly of type $\mathrm{II}_{2}$-III and partly $\mathrm{II}_{1}$. The organic macerals of source rocks of the Sangonghe Formation are mainly vitrinite, and the content of exinite and amorphous organic matter is generally low. The content of exinite and mineral-bituminous matrix of the Badaowan Formation mudstones is high. The $R_{\mathrm{o}}$ ratio of the Jurassic source rock is $0.53 \%-0.79 \%$, which is in the low and critically mature stage. Due to the deep burial of Carboniferous strata, they have not been drilled. According to the sedimentary and seismic facies in the Western Well Pen1 depression, the TOC content of the lower Permian source rock is $3.5 \%$, and that of the middle Permian is $3.0 \%$, which can both reach the good source rock standard with the organic matter of type $\mathrm{I}$ and $\mathrm{II}_{1}$.

\subsection{Geochemical characteristics of the source rocks in the western Changji depression}

The strata were completely developed in the Changji depression. From top to bottom, the strata are Paleogene, Cretaceous, Jurassic, Triassic and Permian, and the Carboniferous strata were locally developed. The source rock is mainly in the Cretaceous, Jurassic and Permian strata.

Based on outcrop analysis, the Permian mudstone is well developed, and oil shale is common. Because of its deep burial in the study area, the Permian mudstone has not been drilled. The TOC content of the Jurassic dark mudstones ranges from $0.13 \%$ to $5.84 \%$, and the average value is $0.92 \%$. The content of chloroform bitumen ranges from $0.0023 \%$ to $0.4888 \%$, and the average value is $0.0350 \%$. The " $\mathrm{S}_{1}+\mathrm{S}_{2}$ " value ranges from 0.02 to $24.82 \mathrm{mg} / \mathrm{g}$, and the average value is $1.35 \mathrm{mg} / \mathrm{g}$. The organic matter abundance of the source rocks of the Badaowan Formation is higher than that of the Sangonghe Formation, with the kerogen mainly of type III and $\mathrm{II}_{2}$ and partly of $\mathrm{II}_{1}$. The Jurassic source rock is at the mature stage. Using the outcrop samples in the eastern Fukang depression and sedimentary facies data, the geochemical characteristics of Permian mudstones in the Yaomoshan, Hongyanchi and Dalongkou areas in the southern margin of the Junggar Basin were analyzed (Fig. 3). Dark grey and dark mudstones were deposited in Permian, and high quality oil shale is locally developed with high hydrocarbon-generating potential. The Lucaogou and Hongyanchi formations in the middle Permian also have high hydrocarbon-generating potential. However, the Guodikeng, Wutonggou and Quanzijie formations in the upper Permian have lower hydrocarbon-generating potential, making poor 

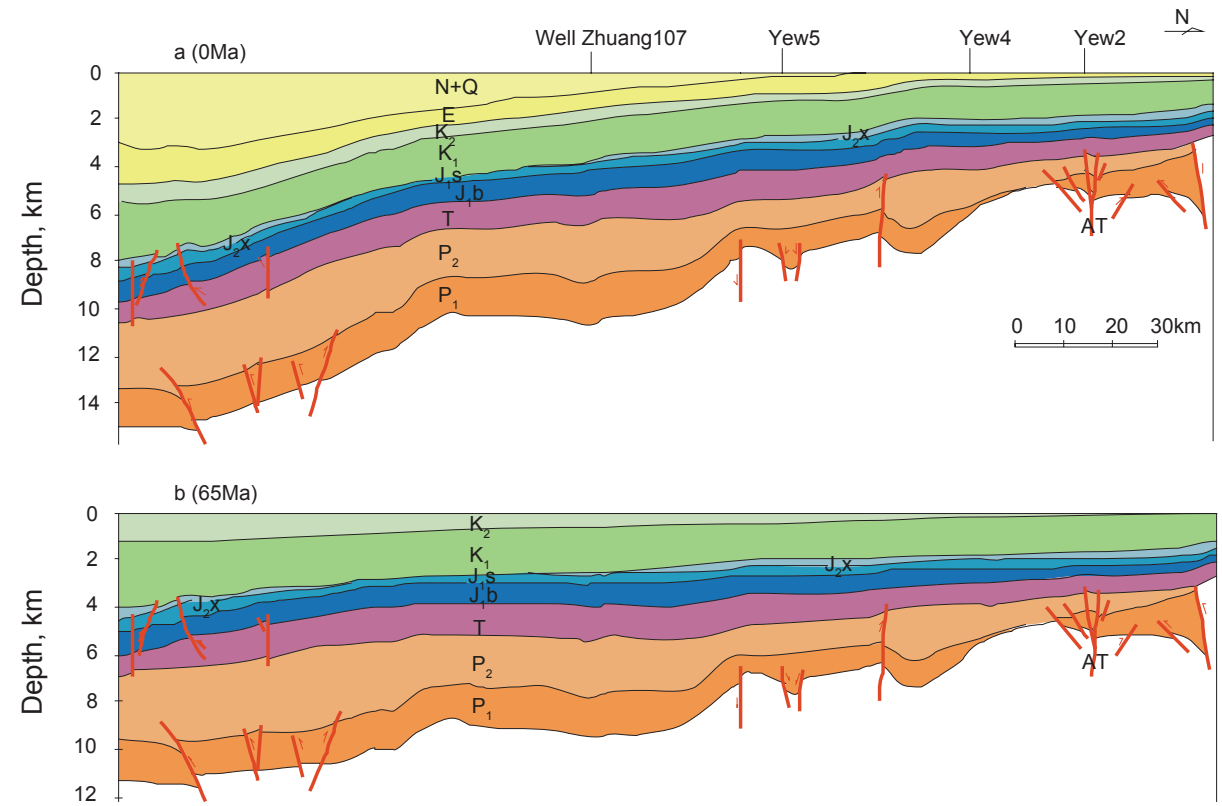

c (145.6Ma)

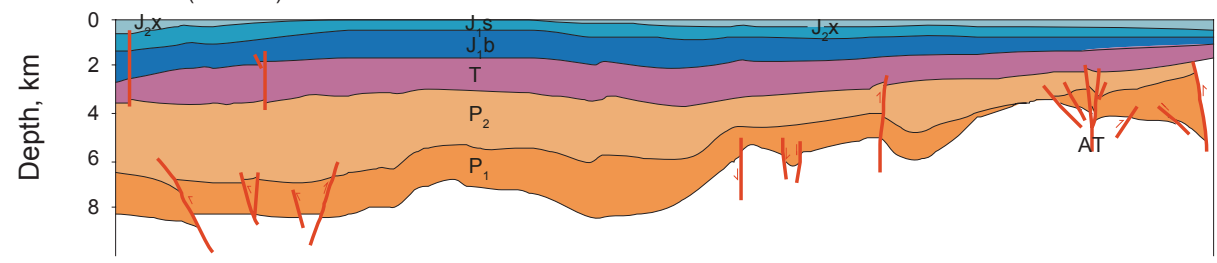

d (178Ma)
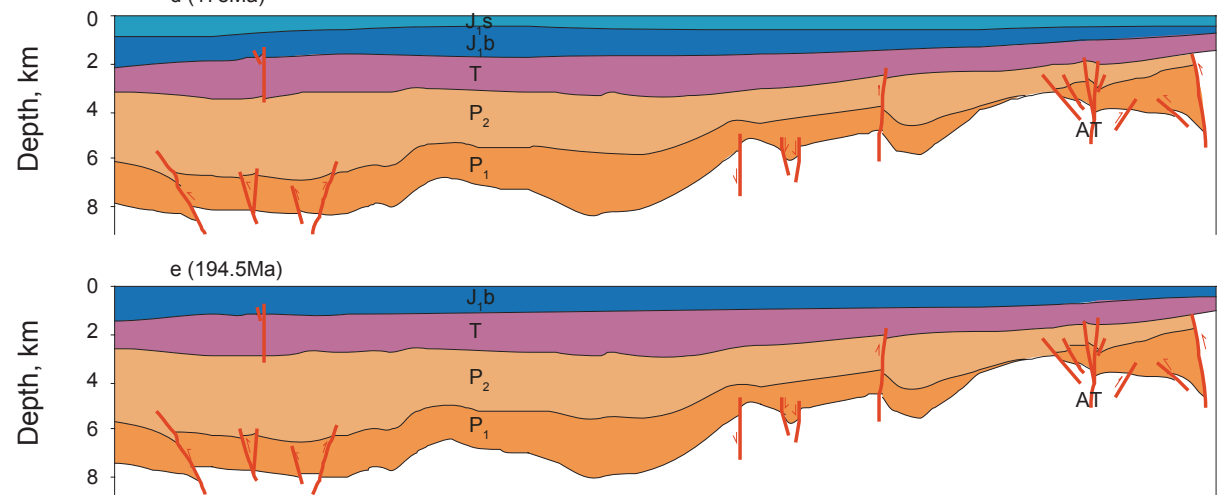

$f(208 \mathrm{Ma})$
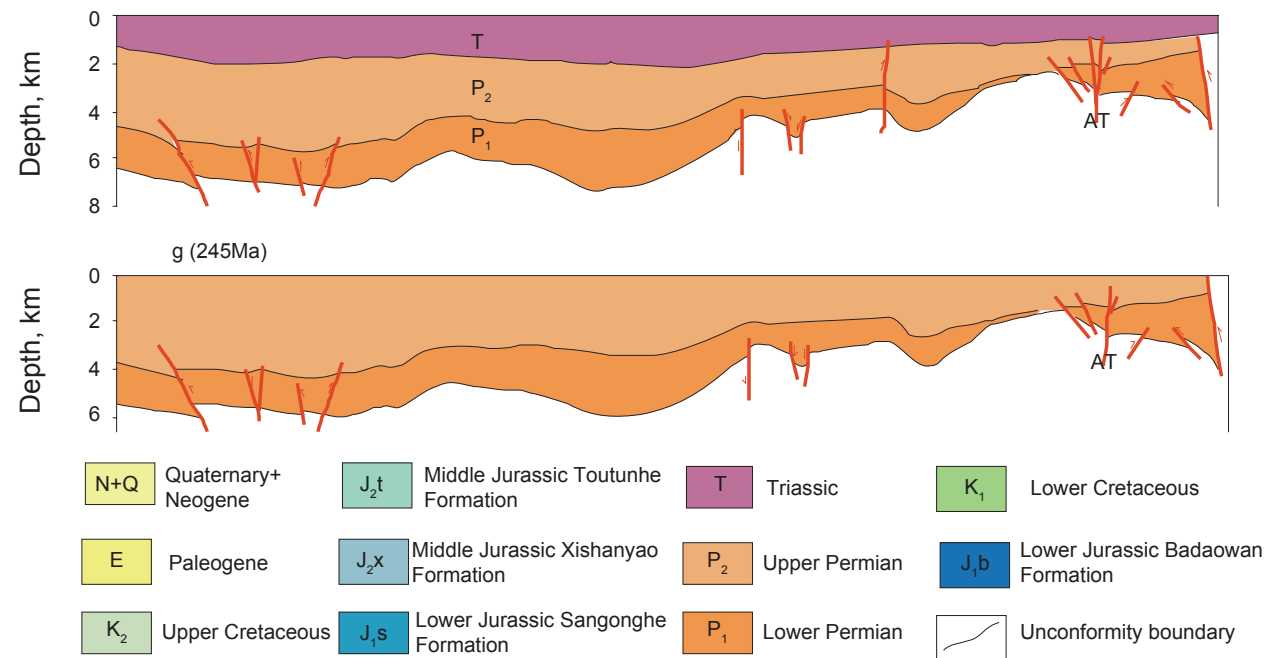

Fig. 2 Tectonic evolution of the Che-Mo palaeohigh (from the internal report on "tectonic evolution, reservoirs, and hydrocarbon accumulation and distribution in the Junggar Basin” in China University of Petroleum (Beijing), 2006) 


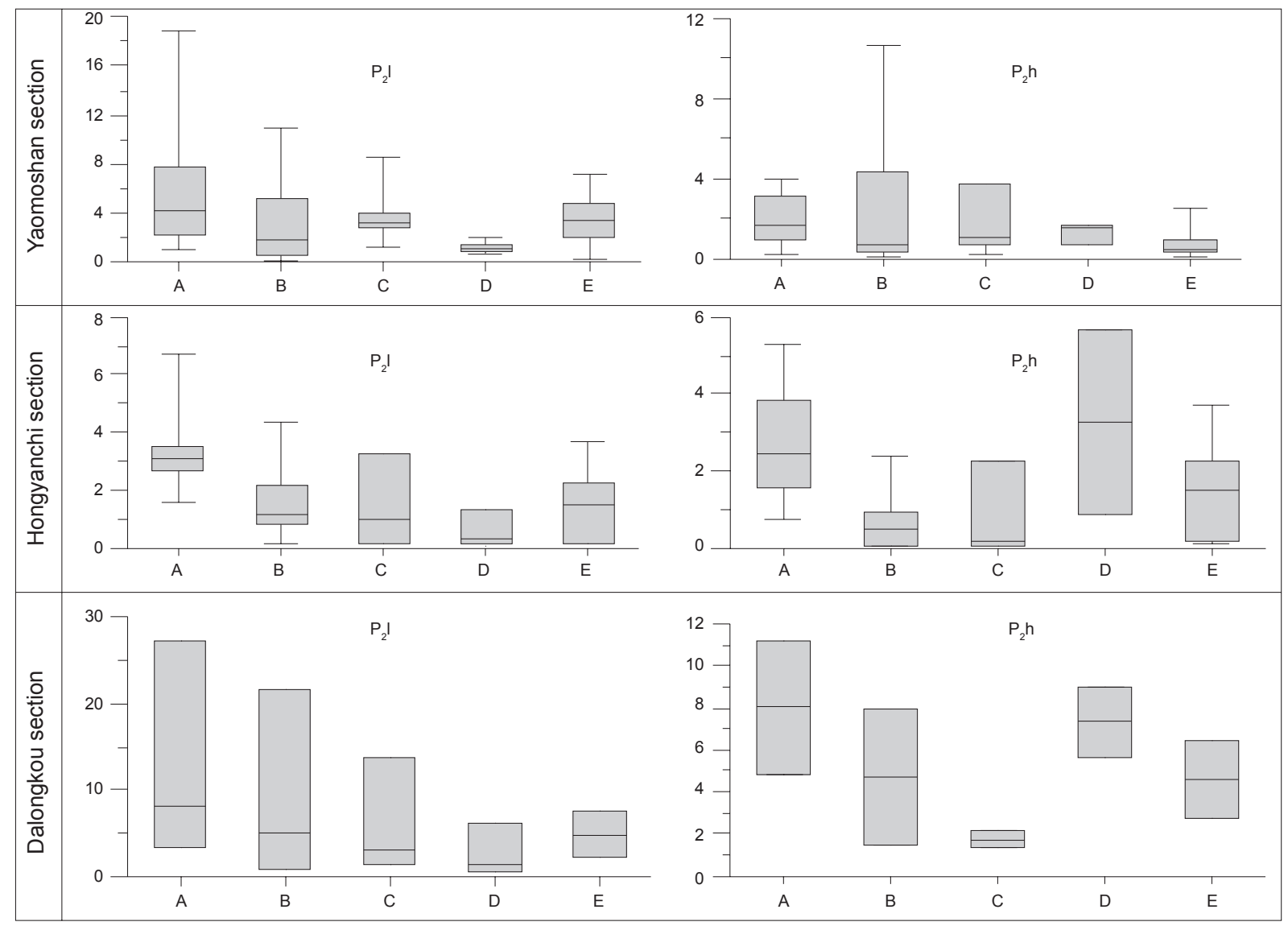

A: TOC, $\%$ B: $\mathrm{S}_{1}+\mathrm{S}_{2}$, $\times 10 \mathrm{mg} / \mathrm{g}$ C: Chloroform bitumen "A", 10-2\% D: Total hydrocarbon, $10^{-2} \mathrm{mg} / \mathrm{g} \mathrm{E}: \mathrm{HI}, 10^{-2} \mathrm{mg} / \mathrm{g}$

Fig. 3 Abundance of organic matter of the Permian source rocks in the southern margin of the Junggar Basin

source rocks. From the distribution characteristics of organic matter, the mudstones of the Permian Lucaogou Formation reach the standard of high quality source rock, and part of the Hongyanchi Formation mudstone also reaches the standard of better source rock. The organic matter in the dark mudstone of the Permian Lucaogou Formation is mainly of type I and II, and the organic matter is almost entirely composed of sapropel. The kerogen of the Hongyanchi Formation is mainly of type $\mathrm{II}_{2}$ and III, and the organic macerals are mainly sapropel and vitrinite.

The Junggar Basin was influenced by the large-scale faulting as well as intense and frequent volcanic activities in the early Permian (Hao et al, 2004). As a result, the coarse clastic rocks and volcanic rocks are mainly developed in the basin with the littoral sedimentary facies in the south. In the late period, the structures became stable and fine grained clastic rocks interbedded with carbonate rocks were deposited in deep water. In the south of the basin, there were mainly lagoon-marine facies deposits, and a set of favorable source rocks was formed in the west of the depression. In the Fengcheng Formation period of early Permian, due to transgression, two hydrocarbon-generating centers were formed in the east and west of the Changji Depression, respectively. Their source rocks are thicker than the Jiamuhe Formation source rock. The western hydrocarbon-generating center is to the north of the Kuitun-Shawan area and the eastern center is close to the Fukang area. In the early period of the middle Permian, the Junggar Basin was again affected by intense tectonic activities. The sea water withdrew from the basin to form a continental sedimentary basin with large differences in terrain. Coarse clastic rocks were generally developed. The south of the basin was relatively low, and mainly fluvial-lakeshore facies were deposited. In the late period, the structures became stable. The fine grained clastic rocks interbedded with carbonate rocks were deposited in deep water. In the south of the basin, the semi-deep lake facies deposition was developed, and a set of favorable source rocks was also formed.

As a whole, in the Permian period, the basin was in a process of marine regression, from the southern margin to the Changji depression. During the early and middle Permian, the water became deeper and the sedimentary facies changed from lagoon facies to sea facies. The depression was always in a deep water environment. So we infer that the source rocks of lower Permian Jiamuhe Formation and Fengcheng Formation and middle Permian Wuerhe Formation are better than the Permian mudstones.

\subsection{Distribution characteristics of source rocks in the hinterland of the Junggar Basin}

The thickness of the potential source rocks can be estimated based on the drilling data in the hinterland of the Junggar Basin, tectonic interpretation of seismic data and sedimentary facies data. As shown in Fig. 4, the thickness 

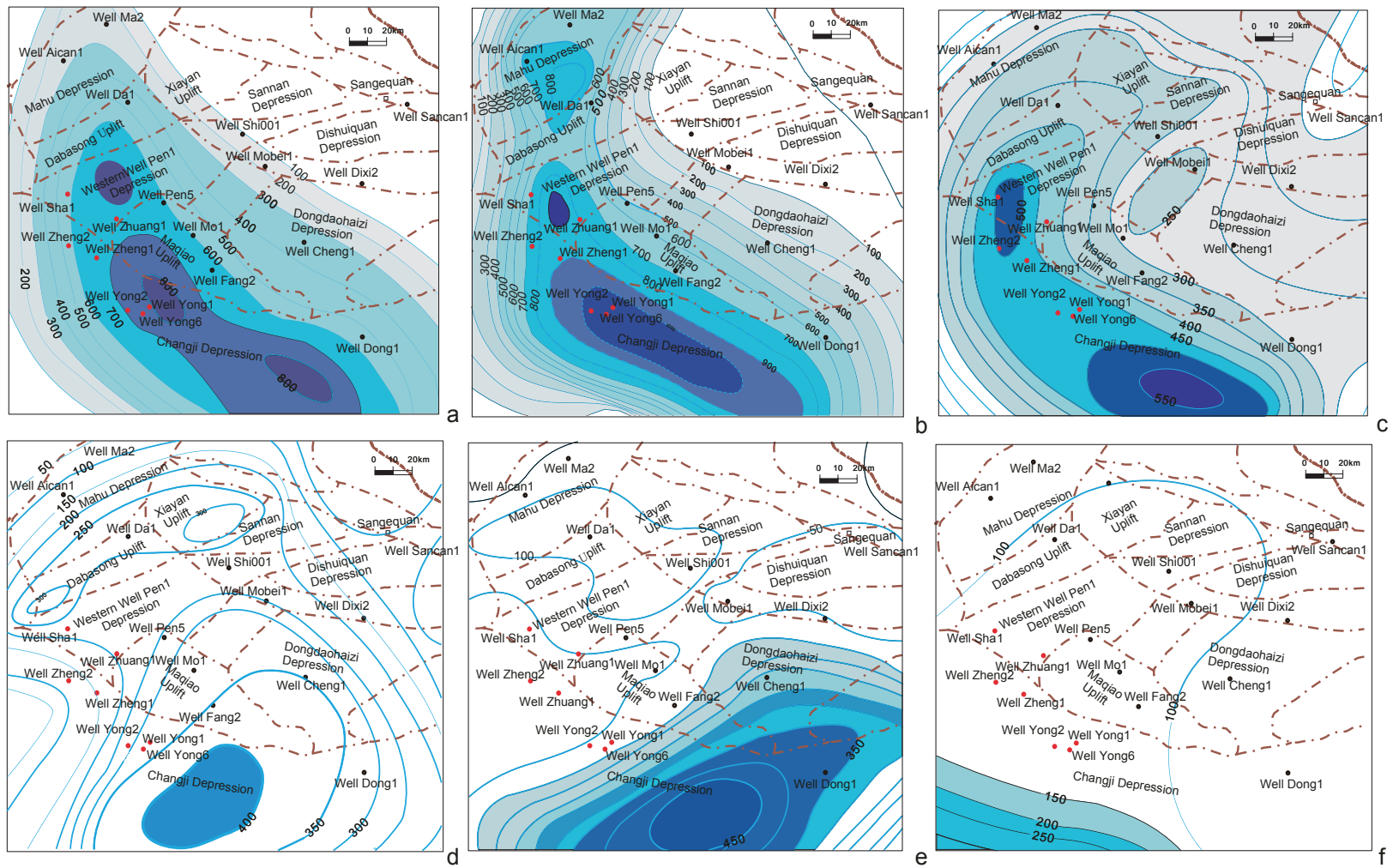

Fig. 4 Distribution of the Jurassic source rocks in the hinterland of the Junggar Basin

of the potential source rocks of the middle Permian in the Western Well Pen1 depression is usually more than 200 $\mathrm{m}$, and the maximum value is $500 \mathrm{~m}$. The thickness of the potential source rocks of the middle Permian in the west of the Changji depression is more than $700 \mathrm{~m}$. In the Western Well Pen1 depression, the west of the Changji depression and the south of the Changji-Urumchi area, the potential source rocks of the lower Permian are thick, up to $500 \mathrm{~m}$. The potential source rocks of Jurassic Badaowan Formation in the Western Well Pen 1 and Changji depressions are relatively thick, about $200 \mathrm{~m}$, and the maximum thickness in the Changji depression is $250 \mathrm{~m}$. The source rocks of Jurassic Xishanyao Formation are poorly developed in the hinterland of the basin, about $50 \mathrm{~m}$ thick. In some areas, they can reach $100 \mathrm{~m}$.

\subsection{Evolution characteristics of source rocks in the hinterland of the Junggar Basin}

Previous research showed that in the early Paleozoic, the Junggar Basin was a typical "hot basin". Before the end of the Triassic, the paleo-geothermal gradient was mainly above $35^{\circ} \mathrm{C} / \mathrm{km}$, and it decreased after Cretaceous. Thus, the basin became a typical "cold basin" (Pan et al, 1989; Zhou et al, 1989; Liu and Zhang, 1992; Wang et al, 2000). Pan et al (1997) studied the thermal history of 13 wells in the Junggar Basin. The results showed that the paleo-geothermal gradient was high from the Carboniferous to the Permian, and decreased gradually from the Triassic to the Jurassic. It decreased from $75{ }^{\circ} \mathrm{C} / \mathrm{km}$ in the Carboniferous to $32{ }^{\circ} \mathrm{C} / \mathrm{km}$ in the late Jurassic. The paleo-geothermal gradient continued to decrease after Cretaceous. In the early Cretaceous, it was $32{ }^{\circ} \mathrm{C} / \mathrm{km}$ and decreased to present $20{ }^{\circ} \mathrm{C} / \mathrm{km}$. Qiu et al (2000; 2002;
2008) obtained the average values by analyzing the data of 60 wells in the Junggar Basin. The paleo-geothermal gradient in the Carboniferous was $43.3{ }^{\circ} \mathrm{C} / \mathrm{km}$, and decreased to $36.3{ }^{\circ} \mathrm{C} /$ $\mathrm{km}$ in the Permian. At the end of Triassic, it was $33.8^{\circ} \mathrm{C} / \mathrm{km}$, and was $28.4{ }^{\circ} \mathrm{C} / \mathrm{km}$ and $22.8{ }^{\circ} \mathrm{C} / \mathrm{km}$ at the end of Jurassic and Cretaceous, respectively. The geothermal gradient was $22.8^{\circ} \mathrm{C} / \mathrm{km}$ at the end of Tertiary, similar to the present value. In addition, the geothermal gradient is different in different areas. For example, from 0 to $4,000 \mathrm{~m}$, the geothermal gradient in the east of the basin is $32{ }^{\circ} \mathrm{C} / \mathrm{km}$, which is the highest. It is $28{ }^{\circ} \mathrm{C} / \mathrm{km}$ in the Luliang uplift area, while it is below $20^{\circ} \mathrm{C} / \mathrm{km}$ in the south of the basin.

\subsubsection{Evolution characteristics of Permian source rocks}

The lower Permian source rocks in the Western Well Pen1 depression entered the threshold of oil generation in the early stage of the late Permian, and reached the oil generation peak in the late stage of the late Permian. The bottom of the middle-upper Permian source rocks entered the oil generation threshold in the middle stage of the late Permian, and reached the oil generation peak in the early stage of Triassic, and then entered the gas-generating stage in the late Triassic period. The bottom of lower Permian source rocks in the Shawan depression entered the oil generation threshold in the late Permian, reached the oil generation peak in the early stage of Triassic, and entered the gas-generating stage in the late Triassic $\left(\mathrm{T}_{3 \mathrm{~b}}\right)$ period. The top of lower Permian source rocks entered the threshold of oil generation in the late stage of Permian, and reached the oil generation peak in late Triassic, and then entered the gas-generating stage in the early Jurassic period. In the late stage of Triassic, the lower Permian source rocks in southern basin were in the highly or over mature stage and the top of middle Permian source 
rocks were in the immature stage. In the late Jurassic, lower Permian source rocks entered the mature stage completely, and in most areas, they were in highly or over mature stage, such as in the Changji and Western Well Pen1 depressions. The middle Permian source rocks almost completely entered the mature stage, and in the Changji and Western Well Pen1 depressions they entered the highly or over mature stage.
In the late Jurassic period, the lower Permian source rocks mostly entered the highly or over mature stage, and began to generate gas. The middle Permian source rocks in the Changji depression entered the highly or over mature stage. At present, all Permian source rocks in the whole basin are mature, and the generation depressions are at a highly or over mature stage (Fig. 5).
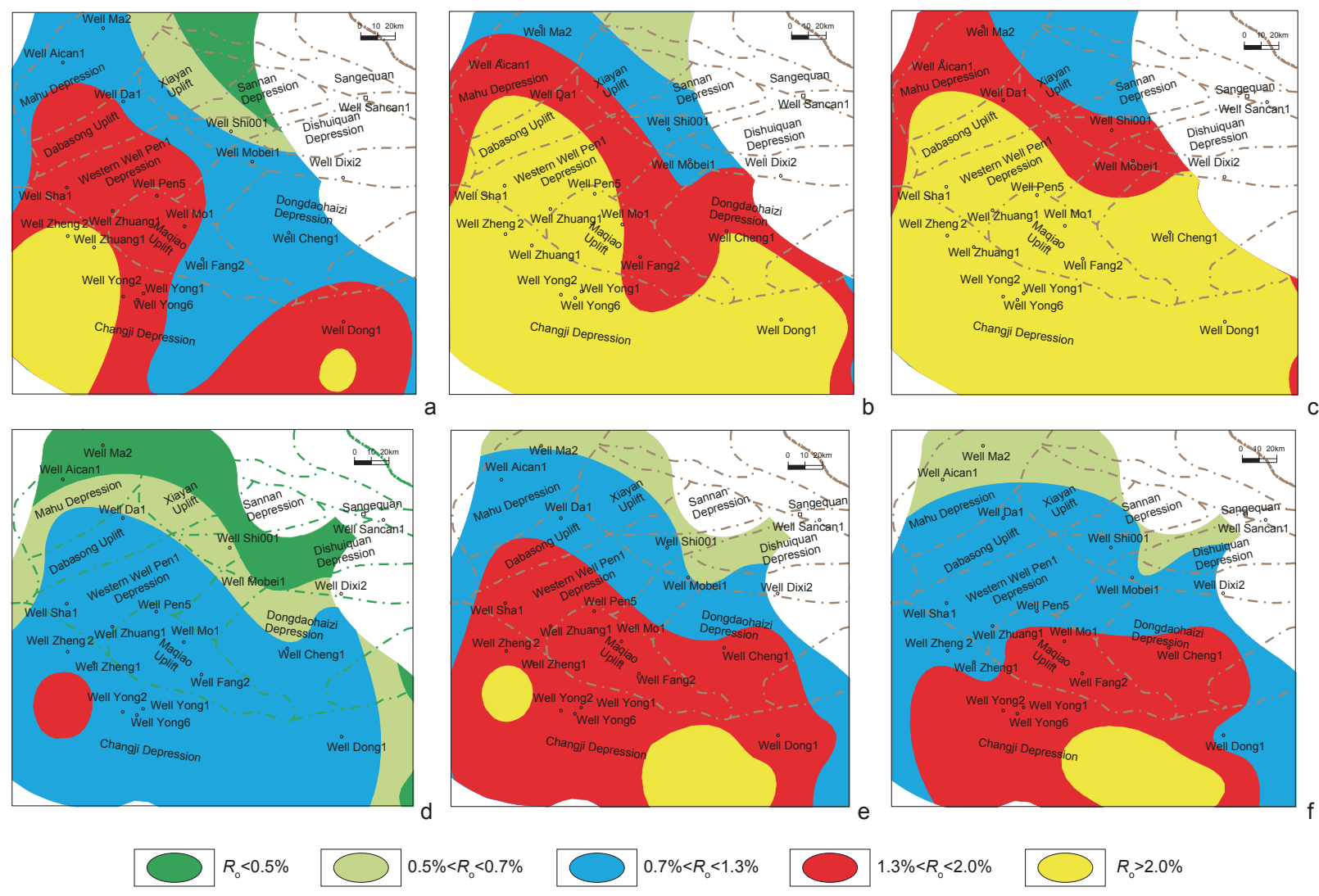

$1.3 \%<R_{\circ}<2.0 \%$

$R_{0}>2.0 \%$

Fig. 5 Thermal evolution of Permian source rocks in the hinterland of the Junggar Basin

\subsubsection{Evolution characteristics of Jurassic source rocks}

The Jurassic source rocks of the Badaowan Formation in the Changji and Western Well Pen 1 depressions entered the mature or over mature stage in the late Cretaceous. In the center of the Changji depression they entered the over mature stage, and mainly generated gas, while the source rocks in the Western Well Pen1 depression were still in the oil generation stage $\left(R_{\mathrm{o}}=0.8 \%-1.3 \%\right)$. Except in the center of the Changji depression, the Jurassic Sangonghe Formation source rocks were mostly at an immature stage in the late Cretaceous. At present, the Sangonghe Formation source rocks are in the mature stage, and in the center of the Changji depression they are over mature. The Jurassic Xishanyao Formation source rocks were at the immature stage in the late Cretaceous. At present, in the center of the Changji depression they are at a highly mature stage and in the Western Well Pen1 depression they are still immature (Fig. 6).

\section{Geochemical characteristics and origin of crude oil in the hinterland of the Junggar Basin}

Commercial oil flows or shows have been found in the
Jurassic and Cretaceous strata in the Moxizhuang, Shawodi and Zhengshacun oil-bearing tectonic belts to the west of the Mosuowan uplift, central Junggar Basin. Because the Western Well Pen 1 and Changji depressions are located on the two sides of the tectonic belts, hydrocarbon sources are adequate, and accumulation conditions are favorable. The crude oil samples were from the lower Jurassic Sangonghe Formation of Well Zhuang1, Zhuang101, Zhuang102 and Zhuang103 in the Moxizhuang tectonic belt, Well Sha1 in the Shawodi tectonic belt, and Well Zheng1 in the Zhengshacun tectonic belt. Geochemical analysis of the samples indicates that the crude oil of the Jurassic in the three tectonic belts can be divided into two types (Table 1). The first type is distributed in the lower Jurassic Sangonghe Formation in the Shawodi and Moxizhuang tectonic belts, while the second type is distributed in the lower Jurassic Sangonghe Formation in the Zhengshacun tectonic belt. There are obvious differences in geochemical characteristics between the first type crude oil and lower-middle Jurassic coal source rocks as well as the source rocks of the Permian Lucaogou Formation in the southern margin of Yaomoshan section. For example, the source rock of the Lucaogou Formation has a low content of 

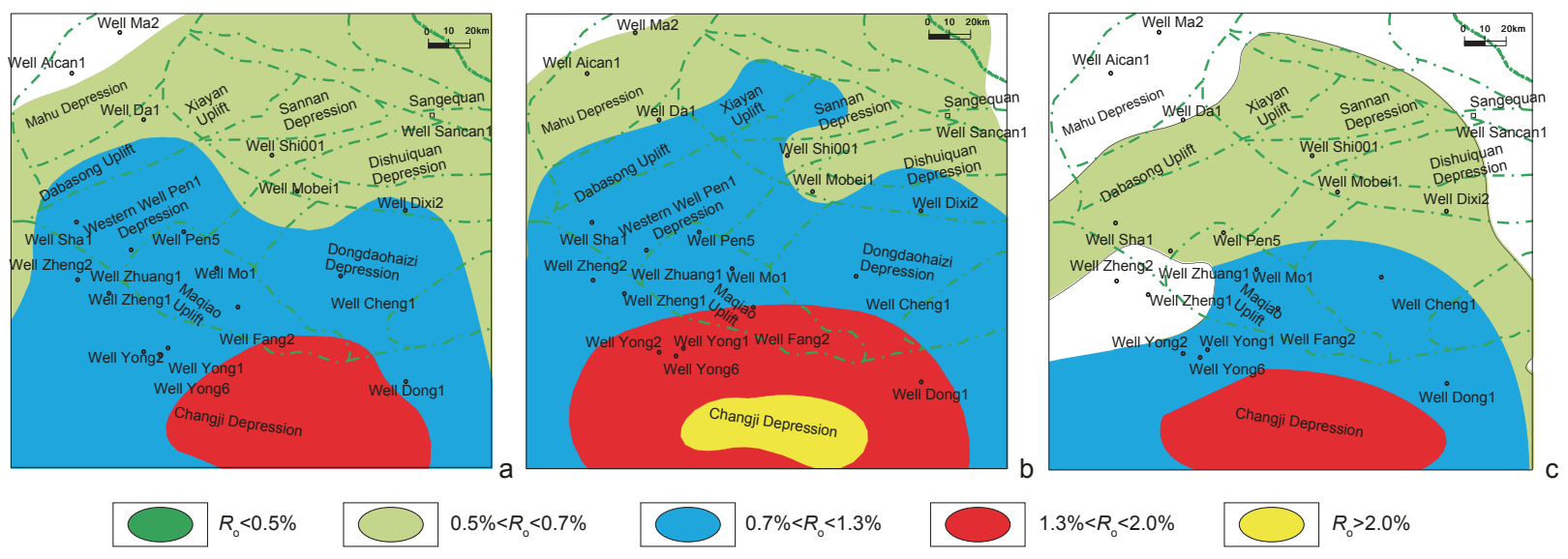

Fig. 6 Thermal evolution of the Jurassic source rocks in the hinterland of the Junggar Basin

gammacerane and $\beta$-carotane and low homohopane index, which is always less than 0.04 , while the average value in crude oil is more than 0.08 . The first type crude oil is similar to the Fengcheng Formation source rock. Both of them have a high content of gammacerane and $\beta$-carotane, and the content of Ts is less than that of Tm. The content of $\mathrm{C}_{20}, \mathrm{C}_{21}, \mathrm{C}_{23}$-tricyclic terpanes increases gradually, and the homohopane index is high. The $\mathrm{Pr} / \mathrm{Ph}$ value of crude oil is higher than 1 , mostly from 1.1 to 1.3 , while that of the Fengcheng Formation source rock is lower than 1. It is inferred that the first type crude oil is mainly from the lower Permian Fengcheng Formation and middle Permian lower
Wuerhe Formation in the Western Well Pen1 depression. The geochemical characteristics of the second type crude oil are different from those of the Wuerhe Formation source rock. Although this type of oil has gammacerane and $\beta$-carotane, their contents are low. The content of $\mathrm{C}_{20}, \mathrm{C}_{21}, \mathrm{C}_{23}$-tricyclic terpanes appears in the shape of a peak, and it is comparable to the Lucaogou Formation source rock in the Yaomoshan section. The content of dibenzofuran is high, and that of fluorene and dibenzothiophene is low. These characteristics are different from those of the first type crude oil. It is inferred that this type of crude oil is from the middle Permian Lucaogou Formation in the Changji depression, or maybe

Table 1 Geochemical characteristics of different types of crude oil in different tectonic belts in the hinterland of the Junggar Basin

\begin{tabular}{|c|c|c|c|c|c|}
\hline Tectonic belt & $\begin{array}{l}\text { Crude oil } \\
\text { type }\end{array}$ & Normal alkane & Isoparaffin & Terpane & Sterane \\
\hline \multirow{2}{*}{$\begin{array}{l}\text { Moxizhuang, } \\
\text { Shawodi } \\
\text { and } \\
\text { Zhengshacun }\end{array}$} & Type one & $\begin{array}{l}\text { single peak, } \\
\text { predominated by } \\
\text { prepeak, low carbon }\end{array}$ & $\begin{array}{l}\mathrm{Pr} / \mathrm{Ph} \text { value varies } \\
\text { from } 1.1 \text { to } 1.3 \text {, high } \\
\text { content of } \beta \text {-carotene }\end{array}$ & $\begin{array}{l}\text { high gammacerane content, } \mathrm{Ts}<\mathrm{Tm} \text {, } \\
\text { rising pattern of } \mathrm{C}_{20}, \mathrm{C}_{21}, \mathrm{C}_{23} \text {-tricyclic } \\
\text { terpanes, high homohopane index }\end{array}$ & $\begin{array}{c}\text { high content of pregnane and } \\
\text { homopregnane, rising pattern of } \mathrm{C}_{27}, \mathrm{C}_{28} \text {, } \\
\mathrm{C}_{29} \text {-regular sterane, high } \beta \beta \text {-sterane } \\
\text { content, especially } \mathrm{C}_{28} \text {-sterane } \beta \beta\end{array}$ \\
\hline & Type two & $\begin{array}{l}\text { double peak, } \\
\text { predominated } \\
\text { by postpeak, } \\
\text { contain } \mathrm{C}_{35+}\end{array}$ & $\begin{array}{l}\mathrm{Pr} / \mathrm{Ph}>2.0, \text { low } \\
\beta \text {-carotene content }\end{array}$ & $\begin{array}{l}\text { high tricyclic diterpene content, peak } \\
\text { pattern of } \mathrm{C}_{20}, \mathrm{C}_{21}, \mathrm{C}_{23} \text {-tricyclic terpanes, } \\
\text { high abundance of } \mathrm{C}_{29} \text {-norhopane, } \\
\text { high gammacerane and Ts content }\end{array}$ & $\begin{array}{c}\text { high content of pregnane and } \\
\text { homopregnane, rising pattern of } \mathrm{C}_{27}, \mathrm{C}_{28} \text {, } \\
\mathrm{C}_{29} \text {-regular sterane, high content of } \\
\beta \beta \text {-sterane, especially } \mathrm{C}_{28} \text {-sterane } \beta \beta\end{array}$ \\
\hline \multirow{2}{*}{ Yongjin } & Type one & $\begin{array}{l}\text { single peak, } \\
\text { predominated by } \\
\text { prepeak, low carbon }\end{array}$ & $\begin{array}{c}\mathrm{Pr} / \mathrm{Ph} \text { value varies } \\
\text { from } 0.67 \text { to } 1.07 \\
\text { high } \beta \text {-carotene } \\
\text { content }\end{array}$ & $\begin{array}{c}\text { high abundance of } \mathrm{C}_{29} \text {-norhopane, peak } \\
\text { or stepped rising pattern of } \mathrm{C}_{20}, \mathrm{C}_{21} \text {, } \\
\mathrm{C}_{23} \text {-tricyclic terpanes, gammacerane } \\
\text { value varies from } 0.53 \text { to } 0.77, \\
\text { high abundance of Ts }\end{array}$ & $\begin{array}{l}\text { high pregnane and homopregnane content, } \\
\text { rising pattern of } \mathrm{C}_{27} \text {, } \\
\mathrm{C}_{28}, \mathrm{C}_{29} \text {-regular sterane }\end{array}$ \\
\hline & Type three & $\begin{array}{l}\text { single peak, } \\
\text { predominated by } \\
\text { prepeak, low carbon }\end{array}$ & $\begin{array}{l}\mathrm{Pr} / \mathrm{Ph} \text { value varies } \\
\text { from } 2.25 \text { to } 2.33 \\
\text { no } \beta \text {-carotene }\end{array}$ & $\begin{array}{l}\text { low abundance of } \mathrm{C}_{20}, \mathrm{C}_{21}, \mathrm{C}_{23} \text {-tricyclic } \\
\text { terpanes with declining pattern, } \\
\text { almost no gammacerane }\end{array}$ & $\begin{array}{l}\text { rising pattern of } \mathrm{C}_{27}, \mathrm{C}_{28}, \mathrm{C}_{29} \text {-regular } \\
\text { sterane, } \mathrm{C}_{29} \text {-sterane } \alpha \alpha \alpha 20 \mathrm{R} \text { predominant, } \\
\text { low abundance of } \mathrm{C}_{27} \text {-sterane } \alpha \alpha \alpha 20 \mathrm{R}\end{array}$ \\
\hline \multirow[t]{2}{*}{ Luliang uplift } & Type one & low carbon & $\begin{array}{l}\text { low } \mathrm{Pr} / \mathrm{Ph} \text { value } \\
\text { and high } \beta \text {-carotene } \\
\text { content }\end{array}$ & $\begin{array}{c}\text { high abundance of } \mathrm{C}_{29} \text {-norhopane, } \\
\text { peak or rising pattern of } \mathrm{C}_{20}, \mathrm{C}_{21} \text {, } \\
\mathrm{C}_{23} \text {-tricyclic terpanes, gammacerane } \\
\text { content varies greatly, low content of Ts }\end{array}$ & $\begin{array}{l}\text { high pregnane and homopregnane content, } \\
\text { "V" pattern of } \mathrm{C}_{27}, \mathrm{C}_{28}, \mathrm{C}_{29} \text {-regular sterane }\end{array}$ \\
\hline & Type two & low carbon & $\begin{array}{c}\text { moderate } \mathrm{Pr} / \mathrm{Ph} \\
\text { value and } \beta \text {-carotene } \\
\text { content }\end{array}$ & $\begin{array}{l}\text { low content of gammacerane, peak or } \\
\text { declining pattern of } \mathrm{C}_{20}, \mathrm{C}_{21}, \mathrm{C}_{23} \text {-tricyclic } \\
\text { terpanes }\end{array}$ & $\begin{array}{l}\text { rising pattern and partially "V" pattern of } \\
\qquad \mathrm{C}_{27}, \mathrm{C}_{28}, \mathrm{C}_{29} \text {-regular sterane }\end{array}$ \\
\hline
\end{tabular}


from the Jurassic source rock.

The Yongjin oilfield is located in the south of the CheMo palaeohigh, and hydrocarbons are mainly distributed in the Jurassic and Cretaceous Tugulu Group. Drilling has just reached the Jurassic Xishanyao Formation, some of the Triassic, but has not reached the Permian. The Changji depression is in the south of the Yongjin oilfield, and has adequate oil sources. Based on the geochemical analysis of the crude oil samples from the Jurassic Xishanyao, Sangonghe and Badaowan formations in Well Yong1, Jurassic Xishanyao Formation in Well Yong2, Jurassic Xishanyao and Sangonghe formations in Well Yong3, Cretaceous Tugulu Group and Jurassic Xishanyao Formation in Well Yong6, and Cretaceous Tugulu Group in Well Yong9, the crude oil of the Yongjin oilfield can be divided into three types (Table 1). The first type is distributed in the Cretaceous Tugulu Group in Well Yong6 and Yong9, the second type is distributed in the Xishanyao and Sangonghe formations in Well Yong1 and Yong3, and the upper Xishanyao Formation in Well Yong2, and the third type is mainly distributed in the Jurassic lower Xishanyao Formation in Well Yong6 and Yong2. Oil source analysis shows that the geochemical characteristics of the first type crude oil are similar to those of the oil in Well Zheng1, but there still are differences. For example, for this type of crude oil, the $\mathrm{Pr} / \mathrm{Ph}$ value is relatively low, the content of gammacerane is high, and the content of $\mathrm{C}_{29} \beta \beta 20 \mathrm{~S}$-sterane is relatively high. This kind of crude oil is different from the extracts from the Triassic, Jurassic and Cretaceous source rocks. The sterane and terpane biomarker compositions of the second type crude oil are similar to those of the crude oil in Well Zheng1 and the Permian Lucaogou Formation source rocks. However, the $\mathrm{Pr} / \mathrm{Ph}$ value is higher than that of the oil in Well Zheng 1 and that of some samples (such as the crude oil of the Xishanyao Formation in Well Yong2) is more than 2, which shows the characteristics of Jurassic coal source rocks. This type of crude oil generally has $25-\mathrm{C}_{29}$ norhopane, which indicates that there is biodegradation. From the total ion chromatogram, the n-alkanes are distributed completely, so it is inferred that there are two stages of filling. The early crude oil with slight biodegradation is from the Permian source rocks. The n-alkanes are biodegraded, while the steranes and terpanes with strong bioresistance are distributed completely. Because of being mixed with the later crude oil from the Jurassic source rocks, the distribution of n-alkanes of the present crude oil shows the characteristics of Jurassic, but the sterane and terpane biomarkers still show the characteristics of Permian. The third type crude oil is coalformed oil. The distribution of n-alkanes is characterized by a single peak, and the $\mathrm{Pr} / \mathrm{Ph}$ value is more than 2 . This type of oil contains very little gammacerane and $\beta$-carotane. The content of $\alpha \alpha \alpha 20 \mathrm{RC}_{27}, \mathrm{C}_{28}, \mathrm{C}_{29}$ steranes appears in the shape of an opposite "L", that of $\alpha \alpha \alpha 20 \mathrm{RC}_{29}$ is high, and that of $\alpha \alpha \alpha 20 \mathrm{RC}_{27}$ is low. These characteristics are comparable with the Jurassic coal source rocks.

There are two types of crude oil in the Luliang area (Wang et al, 2001). The first type of oil is distributed in the Cretaceous Tugulu Group and Jurassic Toutunhe Group. The second type crude oil is mainly distributed in the Jurassic Xishanyao and Sangonghe formations. The crude oil in the
Luliang area (including Shixi, Shinan and Well Lu9 areas in the east of Sangequan uplift) is from the source rocks of the Wuerhe and Fengcheng formations in the Western Well Pen1 depression (Wu et al, 2001; 2004). Chen et al (2003) think that the crude oil in the Luliang area is probably from the Mahu and Western Well Pen1 depressions, and the oil migration pathways in the Western Well Pen 1 depression were deep uncomformity surfaces and reverse fractures, middle normal faults and shallow sand bodies in a successive slope. So the oil accumulation conditions are better than those in the Mahu depression. Wang and Kang (1999) think that the crude oil in the Shixi oilfield is from the Wuerhe Formation in the Western Well Pen1 depression and Zhang et al (2000) also think that the source rocks in the Shixi and Shinan oilfields are probably in the Wuerhe Formation in the Western Well Pen1 depression.

\section{Transformation of source kitchens in the hinterland of the Junggar Basin}

\subsection{Hydrocarbon accumulation stages in northern tectonic belts of Che-Mo palaeohigh}

According to the burial and thermal histories of Jurassic strata in Well Zhuang1, Sha1 and Zheng1, and the homogenization temperature data of fluid inclusions, we obtained the following conclusions. The accumulation stage of the Jurassic Sangonghe Formation reservoir in the Moxizhuang structure was from the late period of the early Cretaceous to the middle Paleogene; that of the Jurassic reservoir in Well Sha1 of Shawodi area was from the late Cretaceous to the late Paleogene; that of the Jurassic reservoir in Well Zheng1 in the Zhengshacun structure was from the Paleogene to present (Fig. 7). According to Liao et al (2003), the reservoir of the Xishanyao Formation in the Luliang oilfield was a secondary reservoir which was formed through the secondary migration and accumulation from reservoirs elsewhere. The accumulation time was from early Cretaceous to Tertiary. The Cretaceous oil reservoirs were the results of secondary migration and accumulation of two-period reservoirs in other places, and the accumulation period was Tertiary.

\subsection{Hydrocarbon generation and expulsion history of source rocks, tectonic evolution and their control on oil accumulation}

The simulation results of source rock evolution history showed that the source rocks in the lower Permian Fengcheng Formation and middle-upper Permian in the Western Well Pen 1 depression reached the highly or over mature stage before the formation of the Che-Mo palaeohigh and the adjustment in the Neogene period. The middle-upper Permian source rocks reached the hydrocarbon generation stage, but the Badaowan Formation source rocks did not generate hydrocarbon. The lower Permian source rocks in the western Changji depression were in a highly or over mature stage and the middle Permian source rocks at the top of lower Wuerhe Formation were at the peak of hydrocarbon generation. The source rocks of the Badaowan Formation reached the main hydrocarbon-generating stage in the middle and late 


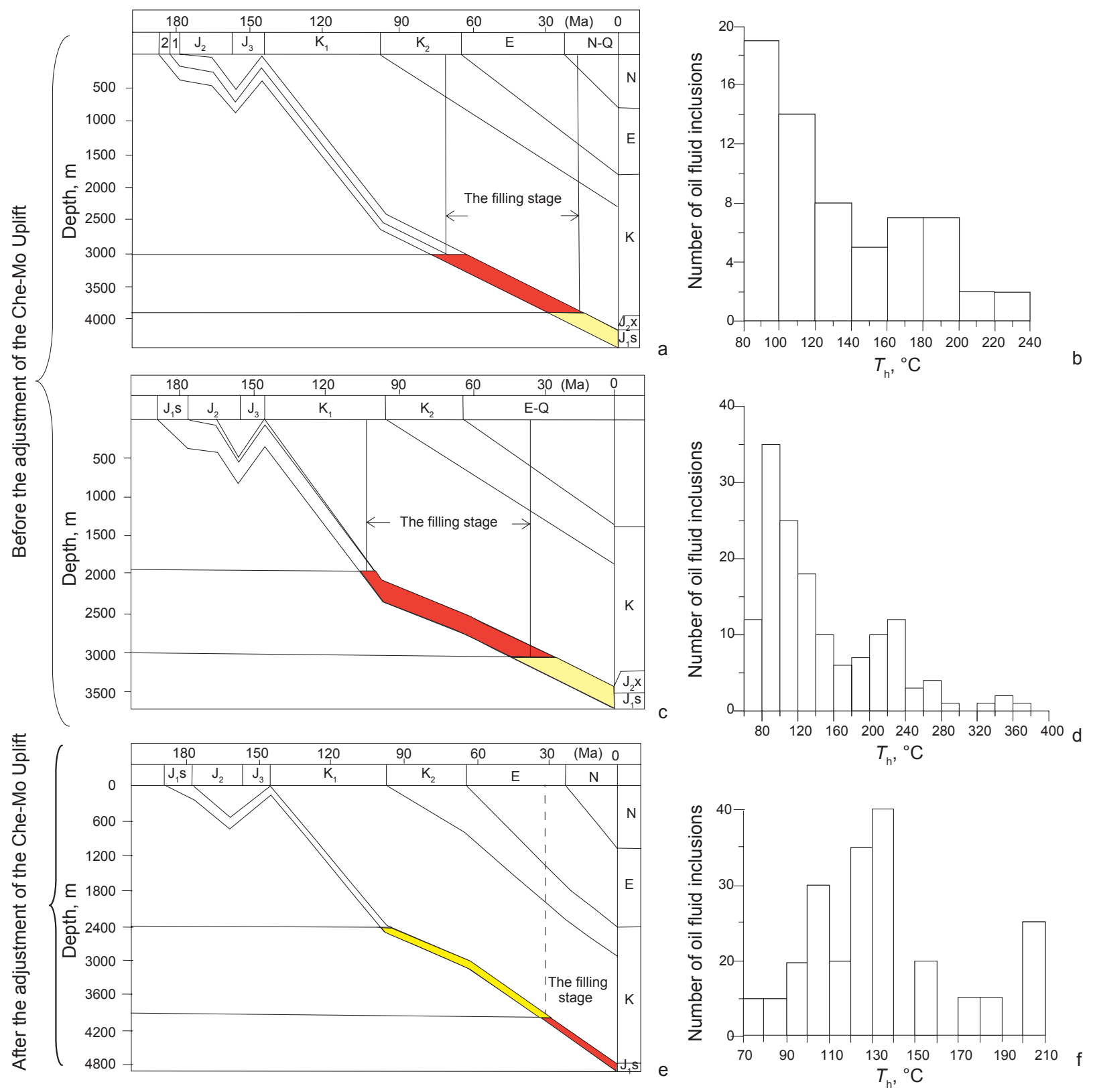

Fig. 7 Buried history and accumulation stages of the Jurassic reservoirs in the hinterland of the Junggar Basin

of this period, which was also the accumulation stage of the Sangonghe Formation reservoirs in Well Zhuang1 and Sha1. The oil was from the middle Permian source rocks in the Western Well Pen1 depression. At this time, the Well Zheng1 area was at the top of the structure, but the analysis of the fluid inclusions showed that there was not a great deal of oil and gas in the Sangonghe Formation. The crude oil of the Xishanyao and Sangonghe formations in Well Yong1, of the upper Xishanyao Formation in Well Yong2 and of the Cretaceous Tugulu Group in Well Yong6 was from the Permian Lucaogou Formation source rocks in the Changji depression. The oil layers in the Well Zheng1 and Yong1 areas are shallow, thus the crude oil was biodegraded to different degrees in different areas. Compared with Well Yong6 and Yong2, Well Yong1 was in the high position of the structure with a relatively lower depth. The crude oil of the Sangonghe and Toutunhe formations was also biodegraded, especially the Toutunhe Formation oil, which had a high relative abundance of $\mathrm{C}_{25}$-norhopane, close to the abundance of $\mathrm{C}_{30}$-hopane. The crude oil of the Sangonghe Formation was buried deeply, but still had a high abundance of $\mathrm{C}_{25}$-norhopane. The Cretaceous crude oil in Well Yong6 suffered only slight biodegradation and had a lower abundance of $\mathrm{C}_{25}$-norhopane. The crude oil of the Xishanyao Formation in Well Yong2 also had a low abundance of $\mathrm{C}_{25}$-norhopane.

During the Neogene, the Che-Mo palaeohigh disappeared and the tectonic pattern with slope in the south and uplift in the north began to form, which can only accumulate oil and gas from the south of the Changji depression. The middle Permian Wuerhe Formation source rock was in the gas generation stage, and the Jurassic source rock was at the peak of hydrocarbon generation. In the study region, oil and 
gas originated from the Jurassic source rocks in the Changji depression. For example, firstly the crude oil migrated and accumulated in the Xishanyao Formation of Well Yong6 and lower Xishanyao Formation of Well Yong2. Next it migrated into the Xishanyao Formation in Well Yong2, Sangonghe and Xishanyao formations in Well Yong1. At last it mixed with the crude oil generated by the Permian source rocks earlier. Because of the tectonic movements, the crude oil from Permian and Jurassic source rocks continued to migrate to the north and then accumulated in the Sangonghe Formation in Well Zheng1. After that, it migrated into the reservoirs from the Fengcheng Formation source rock in Well Zhuang1 and Sha1. The Jurassic oil layers at the stage were deeply buried and the microbial activity was weak, so the crude oil was not biodegraded.

The evolution of the Che-Mo palaeohigh and hydrocarbon generation history of the Changji and Western Well Pen 1 depressions control the hydrocarbon sources of reservoirs in the study region (Fig. 8). Before the adjustment of the CheMo palaeohigh, from Cretaceous to Paleogene, the crude oil in the Zhengshacun, Shawodi, Moxizhuang and Yongjin oilfields was mainly from the Permian source rocks in two depressions mentioned above. The crude oil in the Luliang palaeouplift and Mosuowan area was from the middle Permian Wuerhe Formation and lower Permian Fengcheng Formation source rocks in the Western Well Pen1 depression. At the end of Paleogene, the palaeohigh began to dip to south. The crude oil in the Zhengshacun, Shawodi, Moxizhuang and Yongjin oilfields was from the Jurassic source rocks in the Changji depression. At the same time, the crude oil of the existing reservoirs adjusted to the Well Zheng1. The Jurassic source rocks in the Western Well Pen1 depression were of a lower maturity, and had a small distribution range. The middle Permian source rocks began to generate gas. Only a little gas accumulated in the Luliang palaeouplift and Mosuowan area, and the hydrocarbon generation in lower Permian stopped.

\subsection{Combination and superimposition of hydrocarbon source kitchens in the hinterland of the Junggar Basin}

The reservoirs in the hinterland of the Junggar Basin are characterized by multiple sources and multiple accumulation stages. The Permian source rocks are mainly in the lower Permian Fengcheng Formation and middle Permian Wuerhe Formation. The crude oil in the Luliang and Mosuowan areas is from the middle Permian Wuerhe Formation source

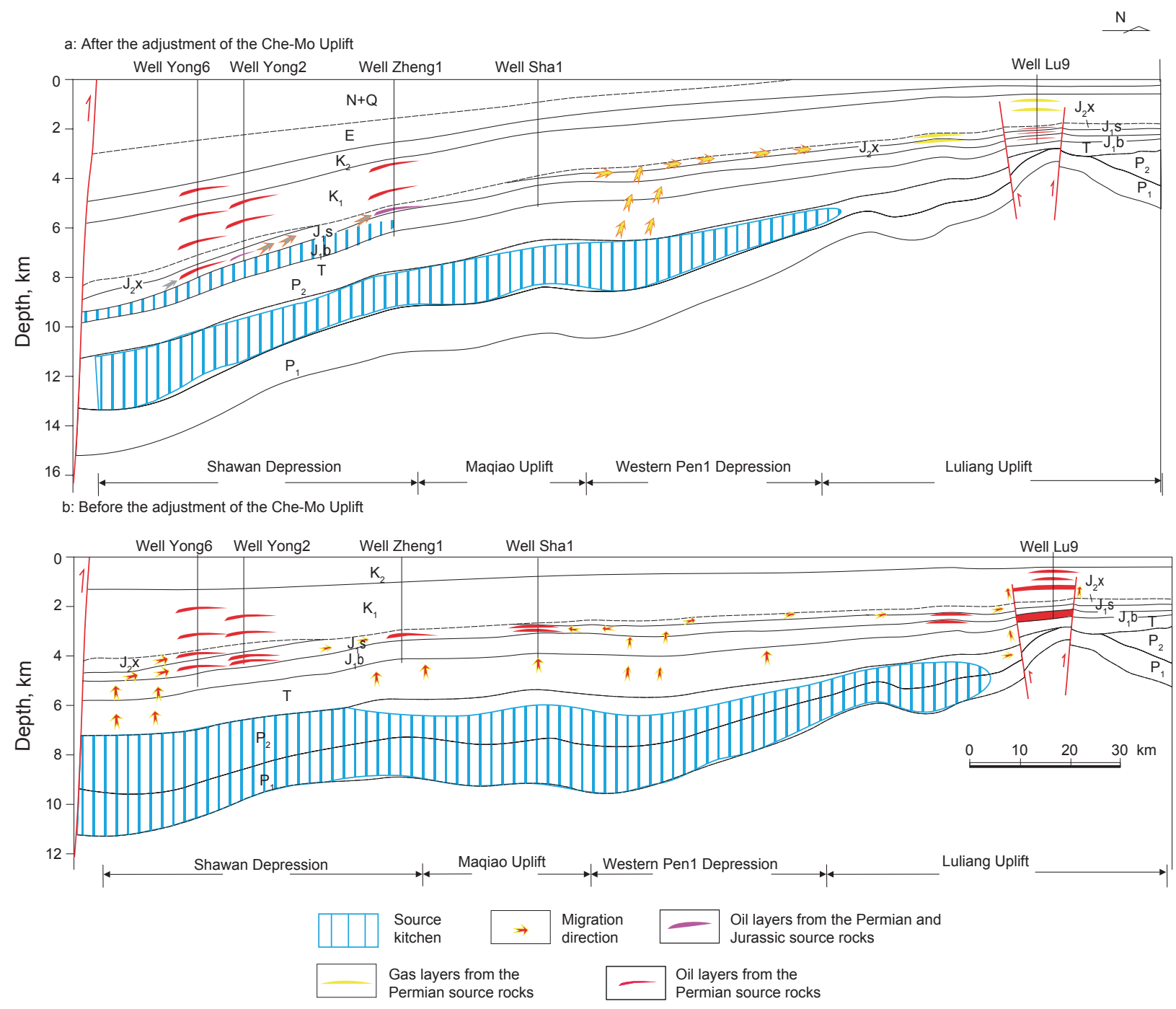

Fig. 8 Hydrocarbon accumulation models in the hinterland of the Junggar Basin 
kitchen in the Western Well Pen1 depression, the crude oil in the Yongjin, Moxizhuang and Zhengshacun areas is from the composite middle Permian source kitchens of Western Well Penl depression and Shawan depression, and the Jurassic source kitchens overlapped later.

From the late Permian to the Triassic, the lower Permian source rocks in the Western Well Pen1 depression entered the threshold of oil generation, reached the peak of oil generation at the end of late Permian and rapidly entered the stage of gas generation. The bottom of the lower Permian source rocks in the Shawan depression had already been in the stage of hydrocarbon generation in late Permian, reached the peak of oil generation in the early Triassic and entered the stage of gas generation in late Triassic. The top of the lower Permian source rocks entered the threshold of hydrocarbon generation at the end of Permian, and reached the peak of oil generation in late Triassic. The bottom of the middle and upper Permian source rocks in the Western Well Pen1 and Shawan depressions entered the threshold of hydrocarbon generation in the middle of late Permian, reached the peak of oil generation in Triassic and entered the stage of gas generation in late Triassic. The source kitchens of the Fengcheng and Wuerhe formations reached the peak of hydrocarbon generation and began to provide oil sources to the central basin, which formed the combination of several source kitchens (Fig. 9(a) and (b)).
During the Jurassic period, the source rocks of the Fengcheng Formation in the Western Well Penl and Shawan depressions reached the over mature stage. The source kitchens on the top of the middle Permian also reached the peak of hydrocarbon generation, began to charge oil into reservoirs in the central basin, and reached the peak of gas generation in Jurassic. In the period of Cretaceous, the Permian source kitchens in the Western Well Penl and Shawan depressions entered the over mature stage. While the Jurassic Badaowan Formation source rocks in the Shawan depression entered the hydrocarbon generation threshold, and reached the peak of hydrocarbon generation, forming effective source kitchens. So the mixed crude oil was from the Permian and Jurassic source rocks in the Zhengshacun area, and the crude oil in Well Yong2 was from the Jurassic source rocks. This indicates that the Jurassic Badaowan Formation source kitchen contributes to the oil in the central basin and is still at the peak of hydrocarbon generation nowadays. The Sangonghe Formation source kitchens entered the threshold of hydrocarbon generation, but limited distribution range led to low contribution to the oil and gas. Thus the Jurassic source kitchens were superimposed in the Shawan depression. The hydrocarbon-generating model in the hinterland of the Junggar Basin was early combination and late superimposition of multiple source kitchens (Fig. $10)$.

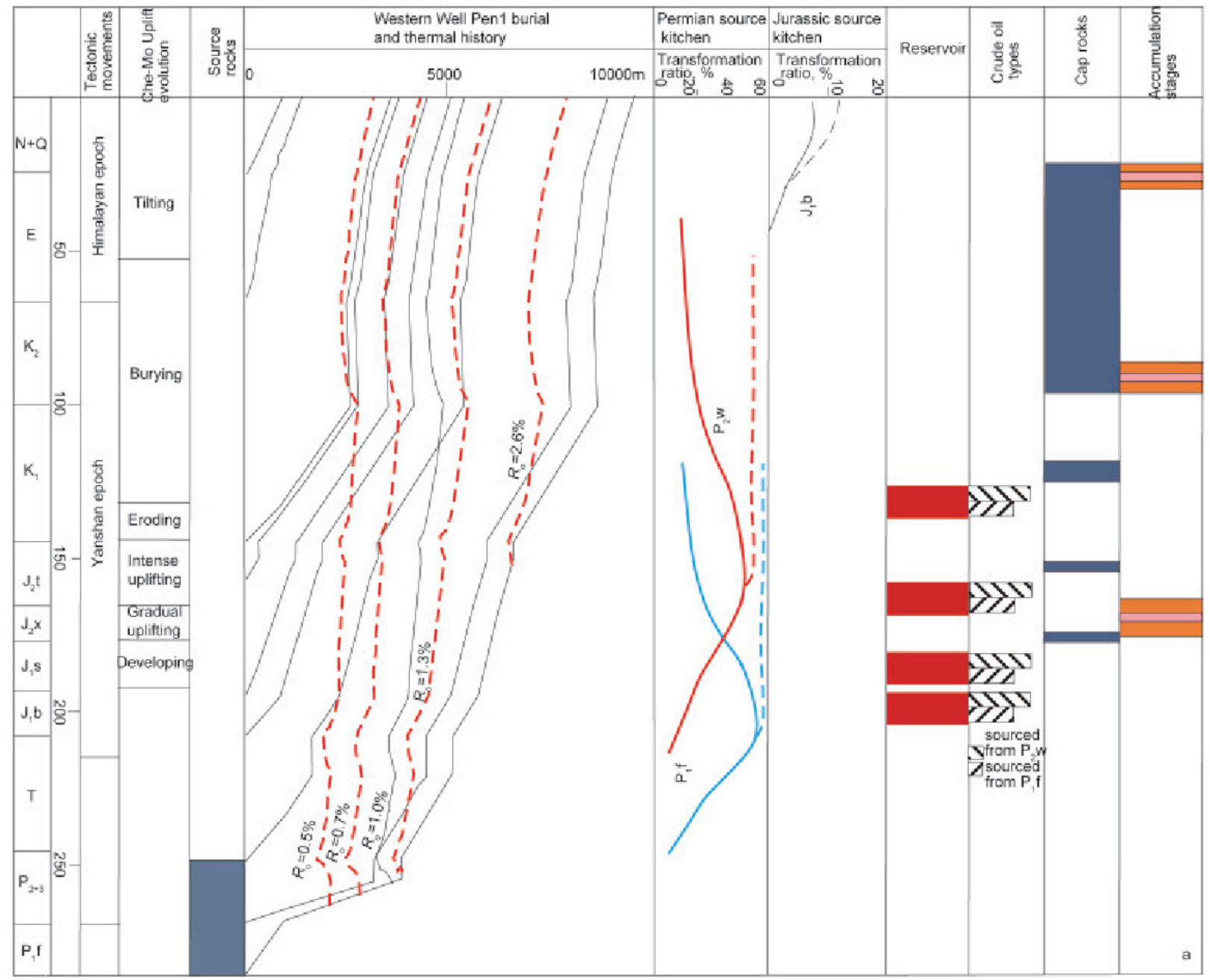




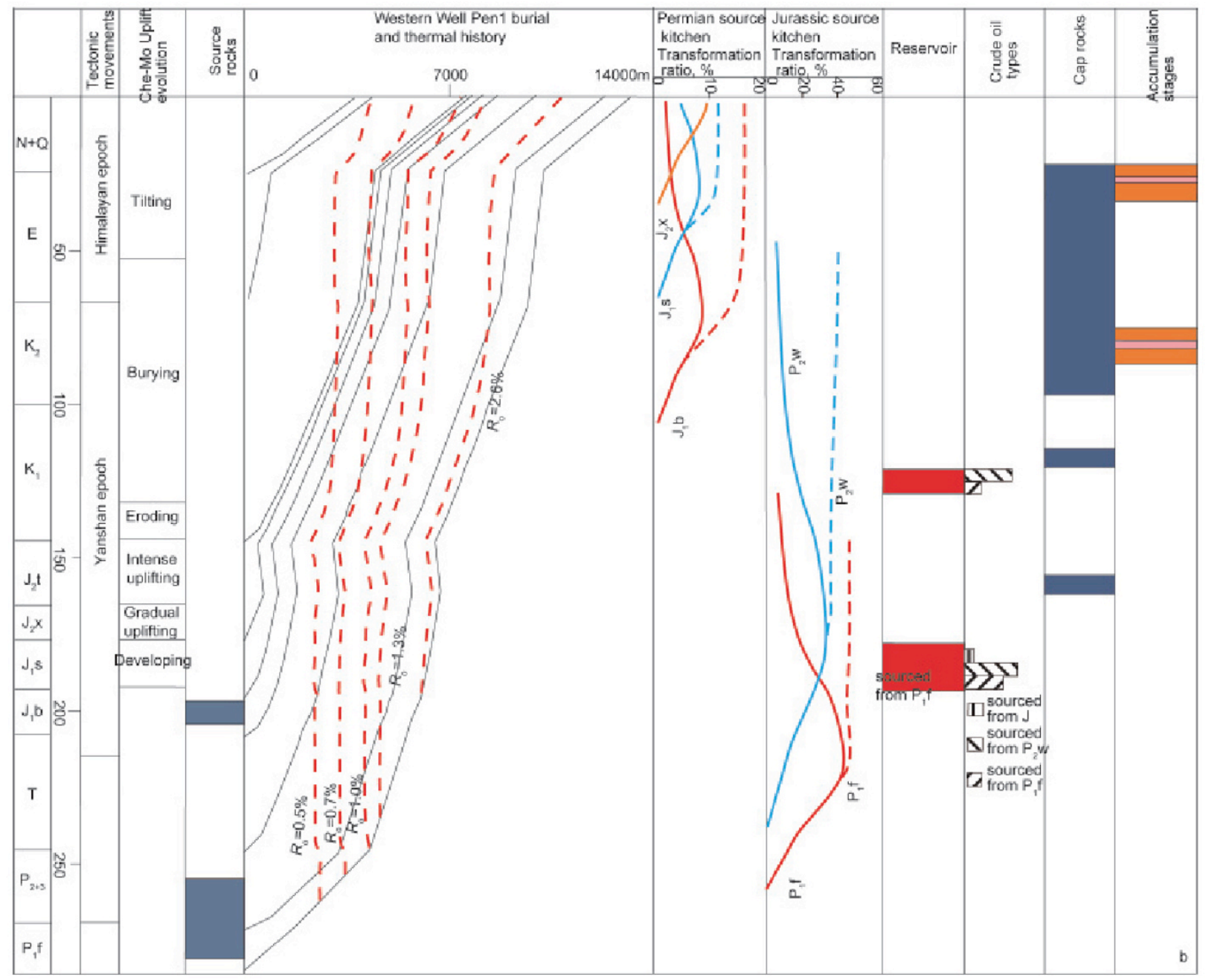

Fig. 9 Hydrocarbon source kitchens and their accumulation effect in the Luliang uplift (a) and Yongjin area (b)

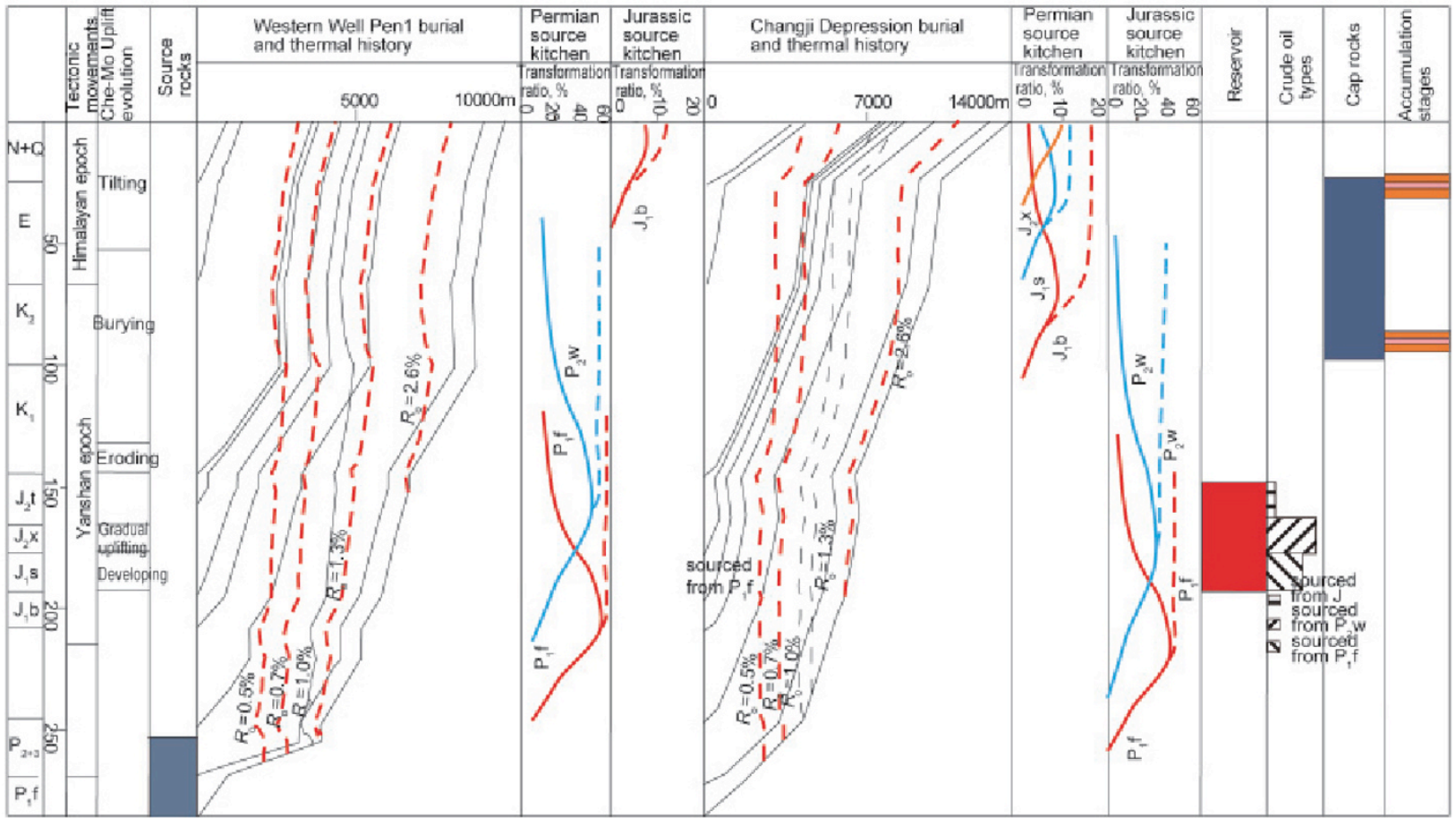

Fig. 10 Hydrocarbon source kitchens and their accumulation effect in the Zhengshacun area 


\section{Conclusions}

1) The hydrocarbon sources are sufficient in the hinterland of the Junggar Basin. The Permian and Jurassic source rocks are well developed in the Changji and Western Well Pen1 depressions. The thickness of the lower-middle Permian source rocks reaches $800 \mathrm{~m}$ and that of the Jurassic Badaowan Formation about $300 \mathrm{~m}$. The abundance and type of organic matter and maturity of the source rocks reach the high quality standard.

2) In the hinterland of the Junggar Basin, the oil sources are complex because of combination and superimposition of multiple hydrocarbon source kitchens. For example, there are three types of crude oil in the Luliang uplift, two types in the Zhengshacun area and three types in the Yongjin area. The crude oil is from the Permian and Jurassic source rocks in the Western Well Pen1 and Changji depressions. The adjustment of the Che-Mo palaeohigh led to the difference of hydrocarbon sources in different geological periods. Before the Paleogene, the Permian source kitchen was generating oil and gas continuously and reached high maturity. After the Paleogene, the adjustment of the Che-Mo palaeohigh led to the subsidence of the Changji depression. The Jurassic source rocks were mature and became the main hydrocarbon source kitchens. However, the Jurassic source rocks in the Western Well Pen1 depression had low maturity and did not generate oil due to the adjustment of tectonic movements. So in the central and southern parts of the Junggar Basin, the Jurassic source rocks generated oil. In the Luliang uplift, the crude oil was from the Permian source rocks in the Well Pen 1 depression and the Jurassic source rocks made no contribution. The crude oil in the Zhengshacun-Moxizhuang tectonic belt was from the Permian source rocks in two depressions and was partially mixed with the oil generated by Jurassic source rocks.

3) In the hinterland of the Junggar Basin, the hydrocarbon accumulation models vary in different tectonic belts due to the combination and superimposition of multiple hydrocarbon source kitchens and accumulation stages. The crude oil in the Luliang uplift was from source rocks of the lower Permian Fengcheng Formation and middle Permian Wuerhe Formation, which was characterized by superimposition of two sets of source kitchens and three accumulation stages. The crude oil in the Yongjin tectonic belt was from the lower Permian, middle Permian and Jurassic source rocks. This was characterized by superimposition of three sets of source kitchens and two accumulation stages. The crude oil in the Zhengshacun tectonic belt was from the combination of source kitchens of lower Permian and middle Permian in the Western Well Pen 1 depression in the early stage and from the superimposition of Jurassic source rocks in the Changji depression in the late stage. The hydrocarbon-generating model in the hinterland of the Junggar Basin was early combination and late superimposition of multiple source kitchens.

\section{Acknowledgements}

This study was supported by the National Basic Research Program in China (2006CB202300). The authors are appreciative of the collaboration with Meng Xianlong and
Hong Taiyuan in the West Branch of Research Institute of Exploration and Development, SINOPEC, and Zhu Lei, Zhu Dan and Shi Quan in China University of Petroleum.

\section{References}

Cai X Y and Liu C H. Main factors for controlling formation of oil-gas reservoir in central part of Junggar Basin. Acta Petrolei Sinica. 2005. 26(5): 1-9 (in Chinese)

Chen Z H, Zha M, Wu K Y, et al. Hydrocarbon migration direction in Luliang section of Junggar Basin. Journal of China University of Petroleum. 2003. 27(2): 19-22 (in Chinese)

Gao X K, Hu W X, Cao J, et al. Study of hydrocarbon migration and accumulation in the Mosuowan-Mobei area, Junggar Basin. Oil \& Gas Geology. 2007. 28(2): 250-256 (in Chinese)

Hao F, Jiang J Q, Zou H Y, et al. Inhibitory effects of overpressure on organic matter thermal evolution. Science in China, Series D. 2004. 34(5): 443-451 (in Chinese)

Kuang J, Liu D G and Li S H. Geologic characteristics and distribution framework of natural gas reservoirs in Junggar Basin. Xinjiang Petroleum Geology. 2001. 22(5): 390-392 (in Chinese)

Liao J D, Kang S F, Li M H, et al. Geochemistry research of oil reservoirs in Luliang Oil Field. Petroleum Geology and Recovery Efficiency. 2003. 10(4): 29-31 (in Chinese)

Liu G B and Zhang H R. The hydrocarbon occurrences and characteristics of geothermal field in Junggar Basin. Xinjiang Petroleum Geology. 1992. 13(2): 99-107 (in Chinese)

Pan C C, Zhou Z Y, Fan S F, et al. Thermal history of Junggar Basin. Geochimica. 1997. 26(6): 1-7 (in Chinese)

Pan C C, Zhou Z Y and Wang Q L. Study of thermal history of source beds in Junggar Basin by apatite fission-track. Oil \& Gas Geology. 1989. 10(1): 35-39 (in Chinese)

Qiu N S, Wang X L, Yang H B, et al. The characteristics of temperature distribution in the Junggar Basin. Chinese Journal of Geology. 2001. 36(3): 350-358 (in Chinese)

Qiu N S, Zha M and Wang X L. Simulation of geothermal evolution history in Junggar Basin. Xinjiang Petroleum Geology. 2000. 21(1): 38-41 (in Chinese)

Qiu N S, Zhang Z H and Xu E S. Geothermal regime and Jurassic source rock maturity of the Junggar Basin, northwest China. Journal of Asian Earth Sciences. 2008. 31(4-6): 464-478

Qiu N S. Characters of thermal conductivity and radiogenic heat production rate in basins of northwest China. Chinese Journal of Geology. 2002. 37(2): 196-206 (in Chinese)

Wang S J, Hu S B, Li T J, et al. The heat flow in the Junggar Basin. Chinese Science Bulletin. 2000. 45(12): 1327-1332 (in Chinese)

Wang X L and Kang S F. Analysis of crude origin in hinterland and slope of northwestern margin, Junggar Basin. Xinjiang Petroleum Geology. 1999. 20(2): 109-112 (in Chinese)

Wang X L, Yang H B, Kang S F, et al. Analysis on oil sources and reservoir formation of Well Lu 9 in Luliang Uplift in Junggar Basin. Xinjiang Petroleum Geology. 2001. 22(3): 213-216 (in Chinese)

Wu X H, Xiang B L and Liu G F. Geochemical study for oil-gas pools of Shixi Oilfield. Xinjiang Petroleum Geology. 2001. 22(1): 35-37 (in Chinese)

Wu X H, Yi H S and Wang C S. Reservoir geochemical characteristics of Shinan Oil Field in Junggar Basin. Natural Gas Industry. 2004. 24(12): 24-27 (in Chinese)

Zhang L P, Wang S J and Qu H. Geochemistry of crude oil and oilsource analysis of Junggar Basin. China Petroleum Exploration. 2000. 5(3): 30-35 (in Chinese)

Zhou Z Y, Pan C C, Fan S F, et al. Geothermal characteristics of the Junggar Basin and its significance to oil searching. Xinjiang Petroleum Geology. 1989. 10(3): 67-74 (in Chinese)

(Edited by Hao Jie) 